\title{
Islamic Finance and the Resources Sector : A Natural Fit for Project Finance
}

\author{
Jason West ${ }^{1}$
}

\begin{abstract}
The investment profile and particularly the horizon of traditional debt financing for projects seldom matches the returns on assets, particularly in the resources and infrastructure sectors where assets have a lengthy construction phase before realising a return. This mismatch in investment duration and risk-return profile is a key weakness of the Western approach to limited recourse borrowing under project financing conventions. The motives underlying Islamic finance however differ from the Western approach permitting longer-term investments and profit-sharing arrangements, subject to the strict practice of Shari'ah law. This paper highlights the advantages of Islamic investment practices over traditional approaches in project financing which can potentially fill a significant gap in funding options for firms in the global resources sector.
\end{abstract}

Key words: Islamic finance, project finance, natural resources, commodities

\section{Introduction}

Companies in capital-intensive industries are increasingly using project finance to fund large-scale capital expenditures. Over 2001-10 on average private companies have deployed over $\$ 200$ billion per annumglobally in project finance (Niehuss, 2010). Islamic finance now makes up around 30 percent of the project finance market in the Arab Gulf states. The decision to use project finance involves an explicit choice regarding both organizational form and financial structure. With project finance, sponsoring firms create legally distinct entities to develop, manage and finance a particular project. These entities borrow on a limited or nonrecourse basis, which places heavier reliance on loan repayments securitized by the project's cash flows rather than on the assets or general credit of the sponsoring organizations. Despite the non-recourse nature of borrowing for capital outlay, projects are generally highly leveraged entities, especially in the resources sector. Debt to total capitalization ratios average 60-70 percent (Esty, 2005) but are often as high as 95 percent.

\footnotetext{
${ }^{1}$ Department of Accounting, Finance and Economics, Griffith University, 170 Kessels Rd, Nathan, QLD, 4111, Australia, Ph: +61 7 37354272, email: j.west@griffith.edu.au
} 
Traditional sources of debt are not a perfect match for project finance opportunities. Often significant differences arise in the investment horizon, cash flow profile and appetite for risk given the complex nature of some projects(Davis, 2005). Thekey question is if firms use project finance as an alternative to traditional on-balance sheet corporate finance, is there a natural source of capital whose characteristicsmatch the risk and return profiles of capital-intensive industries? While recent research has made progress in answering the broader question relating to the use of project financing, little research has been conducted in identifying the ideal investment profile of backersincapital-intensive industries.

Themajor limitation of project finance options available to companies in resources and extractive industriesis the allowable duration for debt financing. Western financial institutions hesitate to engage in limited recourse borrowing arrangements beyond seven years and certainly ten years is generally the longest horizon for nongovernment supported capital investments. Projects developed in the resources sector can often take at least seven to ten years just to return positive cash flows, especially ones that require substantial downstream infrastructure development fortransporting commodities to buyers. As resource projects become more complex and are conducted in regions subject to higher political and economic risks, the investment horizons are becoming greater, with the subsequent retreat of project funding interest from Western banks (Javaid, 2011). This widening gap however appears well suited to the more patient and long-term investment horizons sought by Islamic funds, despite the stricter conditions under which funding may be provided.

With the gradual abatement of the 2008 credit and financial crisis,firms in the resources sector are seeking financing from investors and creditors whose investment horizon constraints are less limited that traditional commercial bank financing. Some firms in the sector are actively seeking to convert their traditional loan agreements into Shari'ah-based loans for two reasons. First, the curtailed eagerness of Western banks to fund risky long-term development has accelerated the search for alternatives. Second, Shari'ahinvestors are seen to be more forgiving to borrowers experiencing troubled times than Western banks. One key idea that is generating this interest is that Islamic funding resembles aninvestment partnership rather than a formallegal debtorcreditor agreement (Lewis, 2008;Rehman,2008), implying that suchfunding contains greater flexibility and can remain in place over a much longer term. Proponents of Islamic funding claim that links withShari'ahfinanciers are a lot more secure than relationships with Western banks (Hasan, 2011). For instance, despite Western banks permitting smallercosts on exit than their Shari'ah investor counterparts, they still retain great flexibility to abandon the project when trouble looms. 
This paper discusses the use of Islamic funds for project financing activities in capital-intensive industries with particular reference to the resources sector, and explores the risk-return profile of Shari'ah-compliant investors. With respect to a number of case studies we show that within the constraints of Shari'ah law Islamic funds are suited for project financing opportunities inthe resources sector and possess many advantages over traditional sources of financing.

\section{Project Financing}

Under the trade-off theory of capital structure a firm should increase leverage to the point where the marginal gain from incremental tax shields equals the marginal loss from incremental distress costs (Harris and Raviv,1991). The total expected cost of distress is equal to the product of the probability of distress and the cost of distress. These include both direct and indirect costs such as reputation damage and missed investment opportunities. The probability that a company will incur significant distress costs depends heavily on its leverage and asset risk. For a given level of asset risk, the probability of distress increases with leverage. Alternatively for a given leverage ratio the probability of distress increases with asset risk. Shareholders sell the safest cash flows to creditors who agree to forgo the upside potential in return for taking a senior claim on the cash flows. With low-risk assets shareholders can sell a majority of the expected cash flows to debt-holders and in return obtain interest tax shields. The reduction in cash flow volatility allows firms to add leverage and increase value from interest tax shields. In the resources sector many projects have relatively low asset risk but can accommodate a correspondingly high level of debt (Esty, 2005). This phenomenon has led to a growth in the debt financing of specific assets securitized by expected cash flows and the asset itself. The most popular mechanism used for this approach is project financing.

Project finance became an established vehicle for companies seeking new ways to finance large natural resource discoveries in the 1970s. Using project finance, British Petroleum raised $\$ 945$ million to develop an oil and gas platform in the North Sea and then Freeport Minerals raised $\$ 120$ million for the Ertsberg copper mine in Indonesia.Project finance is popular in the resources sector because projects can be easily structured as entities legally separated from their sponsors. A great number of resource projects have since been funded using project financing techniques. The major benefits of project financing relate to risks associated with information costs, credit risk and sovereign risk which are key considerations for the resources sector. 


\section{The Limits of Project Finance}

At its core project financing is a form of asset-based financial engineering. It offers certain advantages over traditional forms of corporate financing but its use in the natural resources sector is constrained by two key factors: a general mismatch in the investment horizon between creditor expectations and actual asset returns, and a diminished tolerance for lower than expected cash flows.

The investment horizon of institutions willing to facilitate project financing has steadily decreased over 2007-12 and is unlikely to improve while credit markets remain tight. Table 1 illustrates the change in investment appetite over 2006-12 with respect to project financing in the global energy sector. On average interest rate spreads have increased from around 110 bps to nearly $400 \mathrm{bps}$. The spread of BBBrated bonds in 2011-12 is 130 bps lower than project financing facility costs of assets with a similar credit rating which indicates that the appetite to finance longer-term projects is likely to diminish during periods of relative credit scarcity.In addition the number of syndicated banks in a typical project has grown from around 3 to 8 , the average size of deals has decreasedfrom US\$938 million to US\$772 million and the number of institutions actively engaged in project financing has decreased markedly (Simshauser and Nelson, 2012).Table2 illustrates the average tenor, average facility spread and average size of all global project financing deals in the energy sector over 1981-2007 and 2008-2011. This result highlights the general decline in risk appetite for project financing as an investment class evident by a decline in the average facility size and an increase in credit spreads.

\begin{tabular}{lrrr}
\hline & 2006-07 & 2008-09 & 2011-12 \\
\hline PF spreads (bp) & 110 & 425 & 375 \\
BBB bond spread (bp) & 85 & 360 & 240 \\
PF-BBB spread (bp) & 25 & 65 & 135 \\
Max tenor (yrs) & 12 & 3 & 7 \\
Max gearing & $65 \%$ & $55 \%$ & $60 \%$ \\
MLA Banks & $\leq 3$ & 8 & 8 \\
Syndication Banks & $\leq 3$ & Club deal & 8 \\
Active Banks & 29 & 11 & 14 \\
\hline
\end{tabular}

Table 1: Average spread over LIBOR, comparative BBB-rated bond spreads, maximum tenor and gearing and the number of financial institutions engaging in project financing in the energy sector, 2006-12. Source: AGL Research, Simshauser and Nelson (2012). 


\begin{tabular}{lrrrr}
\hline & $\begin{array}{r}\text { Number of } \\
\text { PFs }\end{array}$ & $\begin{array}{r}\text { Average } \\
\text { facility spread } \\
\text { (bp) }\end{array}$ & $\begin{array}{r}\text { Average } \\
\text { facility size } \\
\text { (US\$) }\end{array}$ & $\begin{array}{r}\text { Global } \\
\text { syndicated } \\
\text { debt (US\$) }\end{array}$ \\
\hline $\mathbf{1 9 8 1 - 2 0 0 7}$ & 2,028 & 143 & 938.0 & $1,902,198$ \\
$\mathbf{2 0 0 8 - 2 0 1 1}$ & 1,112 & 236 & 772.3 & 858,800 \\
Total & 3,140 & 176 & 879.3 & $2,760,997$ \\
\hline
\end{tabular}

Table 2: Global project financing deals, average facility spread and average size in the energy sector in 2011 US\$, 1981-2011. Source: AGL Research, Simshauser and Nelson (2012).

Short term variations in cash flows also create concerns for project financiers. The potential for low or negative cash flows, even over short periods, is monitored carefully by project financiers who have historically not been shy to invoke default actions upon a project experiencing minor difficulties. Financing is not viewed as a form of partnership between lender(s) and borrower but is seen in the more traditional sense of debtor and creditor. Indeed legally the differences are trivial. An avenue is therefore available for new sources of funding that employ an alternate investment model

\section{An Opportunity for Islamic Financing}

Shari'ahoffers unique challenges in banking and finance practices. Islamic economic systems seek to balance economic growth with economic justice, promote prosperity and job creation and lead to the further adoption of Islamic economic and financial practices, see Rehman(2008). A distinctive feature of Islamic finance is that itis assetbased while conventional financiersare monetary-based. 'Money' in an Islamic economy has no intrinsic value; rather its principle purpose is asa medium of exchange. This attracts greater emphasis in Islamic systems than it does in the West. Financing under Islamic principles is typically based on the exchange of, in general, non-liquid assets with the principle aim being to create real assets and inventories. The basic innovations in Islamic project financing in the past decade include the use of istisna (a commission to manufacture contract), murābaha (a cost-plus sale), ijara (a financial lease) and sukuk (an Islamic bond) among others as explored in (Dusuki, 2007).

\section{Islamic Financing Considerations}

Mushäraka(partnership finance) and mudāraba(venture capital finance) are the real and ideal types of Islamic financing respectively, both of which imply partnerships and the sharing of profits. In practice however most Islamic banks apply murābaha, a 
mark-up method of financing trade, which involves relatively little risk for a bank. A murābaha contract occurs where a financial institution purchases an asset, takes title to it and then resells it to the customer at a certain profit added to the cost. While there is confusion concerning the acceptability of murābaha it has been suggested that it is a sale contract rather than a loan, and the transaction being financed must involve a real 'commodity,' see Usmani(2002). The financier must therefore own the 'commodity,' and it is this legal responsibility that justifies the financier's mark-up. Where direct purchase by the financier for resale may not be feasible, under Shari'ah it is permissible for the bank to appoint the client as its agent to purchase the commodity. In this case, it is still the bank that assumes responsibility for any risks involving the commodity. A number of Islamic jurisdictions state that murābaha debt cannot be securitized, thus making sukuk backed by pools of murābaha debt impermissible. The sale of a document representing money is judged to be the same as trading money and thus violates the principle of riba. However the prevailing view among less conservative jurisdictions is that so long as the underlying receivable is connected to a true trade transaction or to a commercial transfer of a non-monetary interest, such a receivable can be traded freely without violating compliance with Shari'ah, see Abdel-Khaleq and Richardson(2007).

There has been some discussion in the literature of the rights and liabilities of those participating in mushāraka and mudārabafinancing contracts, see McMillen(2001), Usmani (2002) and Mahlknecht (2009). All partners have the right to take part in the management of a mushāraka company but their remuneration as agents working for the joint venture is distinct from their returns as investors. Unless stipulated in the initial agreement, any partner has the right to terminate a mushärakaagreement at any time, although a period of notice must be given to the other partners. To prevent a partner withdrawing from a mushärakain its infancy, which may damage the longerterm financial interests of the other partners, it ispermissible to establish an initial agreement that allows a partner to sell his shareholding to the other partners, without the mushärakalapsing (Rehman, 2008). This is an important consideration for syndicated offerings and has been explored in other settings such as housing finance (Smolo and Hassan, 2011) and natural resource development in the Organization of Islamic Conference member states (Abdul-Mumin and Siwar, 2011).

Sukuk offerings are perhaps the most malleable of the Islamic financing structures. A sukuk offering is an asset-backed instrument that represents a beneficial ownership interest in an underlying asset. Sukuk is a certificate that appears like a traditional bond or asset-backed security but is in fact technically neither debt nor equity. Sukuk are normally combined with other forms of Islamic finance (many are mushärakabased), and they are best viewed as a means to raise funds from a wider spectrum of 
investors rather than an entirely separate category of Islamic banking (Richardson, 2006). Any project structure that generates or contributes to the generation of a revenue stream is subject to securitization for the purposes of a sukuk offering. A true asset-backed sukuk is functionally a portion of the title in the assets under it, and as such, it enables a form of partial retention of title for the Islamic financiers (Rosly, 2010).

\section{Retention of title}

A key consideration for structuring Shari'ah-compliant project financing is to ensure that the Islamic financier retains title in the operating assets of the project aligned with the practice of muräbaha. This stems from the Shari'ah requirement that the financier share in the profits and losses of the transaction, see Holden(2007). Structuring projects to accommodate this requirement paves the way for Western financial institutions to cooperate in project financingwith Islamic institutions, and overcomes many Shari'ah prohibitions. Title retention for the Islamic participants not only facilitates the participation of external interests in projects, but also allows for the participation of Shari'ah-compliant financing in almost all regions and investment sectors.

Western lending practices do not call for retention of title of the assets and generally evaluate projected cash flows from the project to determine the likelihood of repayment. Instead of retaining title Western lenders will take a security interest in the project assets to mitigate the risk of default. In project finance, a security interest is a right of a lender to possess and/or sell the project assets in order to satisfy debts to the lender in the event of default. While security interest in the project assets will not completely cover the loan, the nature of the security does provide some protection in the event of default. If the project defaults the Western lenders' security interest provides them with a claim to the assets that takes precedence over other unsecured claims.

If the project defaults, the Islamic lender will already possess title to the project assets that the Islamic funds helped purchase. The Islamic lenders can therefore dispose of the assets to satisfy the outstanding debt obligations. A rahn-adl arrangement can satisfy the dual purpose of allowing for the retention of title in the project assets with Islamic lenders while also enabling Western lenders to have a security interest in the financed assets. From the lender's perspective, a Western security interest and Islamic title retention can function similarly if the project defaults, see Richardson (2006). However it is seldom the case that only a single lender issues a single tranche of debt and as projects grow in size and complexity, the distinction between title and securitization can be a complication though recent experience has shown that this complication does not provide insurmountable obstacles (Rehman, 2008). 


\section{Limited-recourse lending using Shari'ah funds}

Shari'ah-compliant project financing is available in Western nations via a mechanism that retains title in the project's assets by the Islamic lenders. Sukuk offerings are popular in the Middle East. Most offerings are asset-based meaning that investors structure the purchase from the originator to buy back the assets on either a scheduled or early redemption. In contrast, the less common asset-backed securities issued by Islamic finance institutions rely on a securitization that involves asset transfers from an originator into a trust or similar SPV with sukuk issuance by that SPV and payments on the sukuk derived from the payments received in respect of those transferred assets. Asset-backed sukuk holders hold fractional undivided ownership interest in an asset or pool of assets and are thus a form of partial title in the underlying asset. Asset-based sukuk necessarily depends on the credit of the issuer. Historically asset securitization has been rare due to the inability to obtain credit ratings, although some sovereign issues have been proxy rated to match the rating of sovereign credit see McMillen(2001).

\section{Shari'ah funding for the resources sector}

Of great interest to Shari'ah -compliant financing is the possibility of joint ownership of mineral rights, the ability to transfer a mineral estate without transferring property and the ability to separate operating interest from a passive interest that receives only income from production. The ability to carve out well-defined interests with clearly established attendant rights under law fits appropriately with the Shari'ah emphasis on ensuring clarity in the description of the subject matter in the investment agreements.

In many developed countries such as the US, Canada and Australia, mineral estates (ownership of minerals or oil/gas in the ground) and interests derived from them (royalties) are legally defined as a form of real property. As real property with welldefined rights in law ownership in mineral projects can be easily transferred, in whole or in part, in a variety of ways. Both privately-owned and government-administered mineral leases can be severed, subleased, assigned or encumbered without necessarily altering their characterization as real property. Mineral rights laws further allow for the transfer of certain kinds of partial ownership rights, so that one party may control the working interest and operate the leasehold while other parties may hold passive royalty interests (investors who neither participate in operations nor bear any costs of development). Thus ownership can be tailored to the needs of project investors by allowing for the creation of indirect beneficial ownership interests that can be held by Islamic investors, which is critical for Shari'ah compliance. Interests in mineral leaseholds may also enjoy certain protections in bankruptcy which can improve the 
securitization process (Richardson, 2006). Importantly mineral assets can be mortgaged and investors can hold security interests which permits the maintenance of collateral in the event of a breach of contract by the borrower. Therefore in terms of legal structure, Islamic finance and the laws governing minerals and oil/gas in many developed countries can offer ideal partnership opportunities.

Figure 1 illustrates a Shari'ah-compliant project financing structure for a resources project. Each component of the project must be Shari'ah-compliant including the sources of funding (sukuk, mudāraba and murābaha), commodity off-take (Shari'ahcompliant formal undertaking), construction contracts (istisna'a) and leases (ijara).

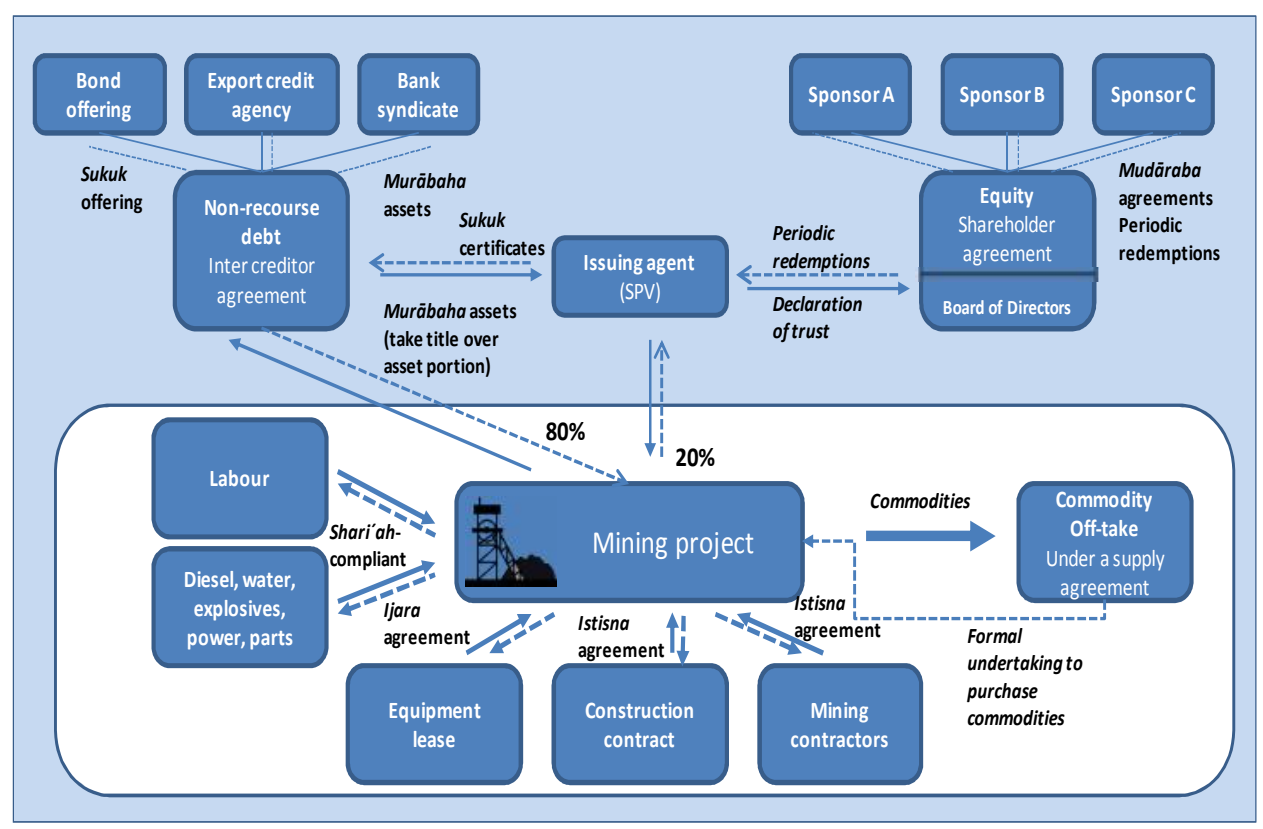

Figure 1: Project finance structure for a resource project using Shari'ah-compliant financing.

An ijara agreement is an Islamic finance lease (or sale-leaseback) used to purchase property, plant or machinery, see Tacy (2006). The lessor leases the assets for a set term at an established rental price and at lease termination the assets can either revert back to the lessor or be acquired by the lessee. Unlike traditional leases, there can be no predetermined sales price for the asset at the end of the term, and the lessee cannot be required to purchase the asset at the end of the term. Also the financier is generally responsible for maintaining insurance. Therefore ijara are more akin to operating leases rather than capital leases. In the context of the resources sector an ijara is an 
ideal mechanism for leveraged lease financing of capital equipment including processing plants, trucks, deepwater platforms and drillships. Critically however in the context of a sukuk offering the value of such equipment should not represent a material percentage of the total financing amount, see Vishwanath and Azmi(2009). Ijara agreements are not prevalent in the resources sector however they are a legally robust substitute for conventional leverage lease or sale-leaseback structures within Shari'ah-compliant financing. In contrast istisna'a is a vehicle for the financing of large infrastructure projects and is currently the most widely used Shari'ah compliant funding of long-term project financings. With istisna'a agreements assets are constructed for the project. Such assets can include processing plants, rail and port facilities, refineries and petrochemical plants.

\section{The Investment Profiles of Loan Facilities}

Anecdotal observations indicate that Western financial institutions tend to avoid commitment to investment tenors greater than around 7 years, see Gilson, John and Lang(1990) and Esty and Megginson(2003). This has resulted in the adoption of alternative project finance structures over the past decade. The generally high cost of resource projects as well as other inefficiencies in the business cycle over 2000-12 has also resulted in a shortening of the maturity of liabilities manifest in the shortening of debt maturities, see Mian and Santos(2011). Frictions arising from asymmetric information are more severe at longer horizons relative to shorter horizons and so beyond a certain maturity adverse selection is too severe for financing to be sustained. Specifically there is asymmetric information about the riskiness and default probabilities of firms.

To analyze the differences between sources of funding for the resources sector we examine a sample of data that compares loan statistics among categories. The nonIslamic data for the period 1980-1999 used in this analysis is the Loanware database provided by Capital Data. This database contains detailed historical information on a great number of syndicated loans and related banking instruments booked on international capital markets. From 1999-2010 the data was sourced from Thomson Reuters financial database. In each case we only extracted data related to the global mining and natural resources sector. Using a sample of over 10,000 syndicated loans with a notional value of around US\$3 trillion we compare the financial characteristics and geographic and industrial distributions of project financed loans with various non-project finance sub-samples and syndicated loans. Islamic fund data was

obtained from the Liquidity Management Centre (LMC) Bahrain database over the period 1980-2010. 
Table 3 illustrates the main characteristics of each loan type used by firms in the global resources sector. The table presents several loan structure variables as well as the use for which a loan is arranged. While most are self-explanatory we define a loan as having currency risk if the denomination of the loan (and its currency of repayment) differs from the currency of the borrower's home country. The data results over 1980-2000 are largely similar to the mining and natural resources data observed in Kleimeier and Megginson(2000) which we have used to cross-reference our results. The third column provides the main characteristics of all known sukuk offerings over 1980-2010 from the LMC database.

Based on t-tests comparing the values of each variable in the project financing sample with the corresponding values in the all syndicated loan sample and in the other loan purpose sub-samples, we found that almost all differences between the project financing sample values and the corresponding values for other loan categories, in particular with sukuk offerings, are statistically significant.

Average spreads are lower for project finance loans (132 bps) than they are for the full sample of all syndicated loans (141 bps), treasury loans (185 bps) and capital structure facilities (139 bps). It is generally assumed that the spread for project finance facilities exceeds non-project finance loans due to the nature of limitedrecourse lending as well as the higher perceived risk levels of most projects. The average maturity of project finance facilities (9.6 years) is well in excess of full sample of syndicated loans (4.2 years) and other facility types (between 4 and 5.1 years). The average spread for sukuk offerings observed over the period was $137 \mathrm{bps}$ with an average maturity of 7.4 years which is similar to project finance facility spreads and tenors. This implies that sukuk buyers are already relatively comfortable with these risk levels for assets with longer-maturities.

The level of fees and the number of participating institutions indirectly indicates that the provision of project finance facilities demand greater compensation than other loan types. The total average levels for commitment and participation fees for project finance facilities (101.3 bps) are significantly higher than the levels for the full sample of syndicated loans (76.3 bps) and for the other facility types with an exception for general corporate loans which have a slightly higher total average fee. The total fees are, however, largely similar to the total average level for commitment and participation fees for sukuk offerings (114 bps) indicating a relative alignment in complexity of both project finance and sukuk facilities. Additionally, the average number of banks participating in project finance facilities in the resources sector (4.1 banks) is different from the average for all loans in the resources sector ( 7.3 banks) and other loan types. 


\begin{tabular}{|c|c|c|c|c|c|c|}
\hline & $\begin{array}{c}\text { All } \\
\text { syndicated } \\
\text { loans }\end{array}$ & $\begin{array}{c}\text { Project } \\
\text { finance } \\
\text { loans }\end{array}$ & $\begin{array}{l}\text { All sukuk } \\
\text { issues }\end{array}$ & $\begin{array}{c}\text { Corporate } \\
\text { treasury } \\
\text { loans }\end{array}$ & $\begin{array}{c}\text { General } \\
\text { corporate } \\
\text { loans }\end{array}$ & $\begin{array}{c}\text { Capital } \\
\text { structure } \\
\text { loans }\end{array}$ \\
\hline Total loans $^{\wedge}$ & 1,356 & 311 & 291 & 227 & 466 & 288 \\
\hline Total volume $(\$ U S \text { bn })^{\wedge}$ & 197,211 & 29,230 & 17,996 & 40,258 & 47,995 & 68,529 \\
\hline $\begin{array}{l}\text { Average loan size (\$US } \\
\text { m) }\end{array}$ & $128^{*}$ & 92 & $298^{*}$ & $177^{*}$ & $85^{*}$ & $181^{*}$ \\
\hline $\begin{array}{l}\text { Median loan size (\$US } \\
\mathrm{m})^{\wedge}\end{array}$ & 70 & 81 & 200 & 85 & 50 & 100 \\
\hline Average tranches & $1.7^{*}$ & 2.4 & $2.5^{*}$ & $2.5^{*}$ & 1.4 & 1.7 \\
\hline $\begin{array}{l}\text { Average spread (over } \\
\text { LIBOR, bp) }\end{array}$ & $141^{*}$ & 132 & $137^{*}$ & $185^{*}$ & $115^{*}$ & $139 *$ \\
\hline Average maturity (yrs) & $4.2 *$ & 9.6 & $7.4^{*}$ & $5.1^{*}$ & 4.0 & $4.2 *$ \\
\hline $\begin{array}{l}\text { Average number of } \\
\text { syndicate banks }\end{array}$ & $7.3^{*}$ & 4.1 & $4.2 *$ & $2.7^{*}$ & $3.8^{*}$ & 6.6 \\
\hline Average initial fee (bp) & $41^{*}$ & 44 & $84 *$ & $39.5^{*}$ & $36^{*}$ & $33.7 *$ \\
\hline $\begin{array}{l}\text { Maximum participation } \\
\text { fee (bp) }\end{array}$ & $35.3^{*}$ & 57.3 & $30 *$ & $56.1^{*}$ & $32.7 *$ & $34.1 *$ \\
\hline $\begin{array}{l}\text { Currency exposed loans } \\
(\%)^{\wedge}\end{array}$ & 36.7 & 72.9 & 77.9 & 11.5 & 45.0 & 22.2 \\
\hline $\begin{array}{l}\text { Loans with covenants } \\
(\%)^{\wedge}\end{array}$ & 37.2 & 5.8 & 7.2 & 46.6 & 21.3 & 46.4 \\
\hline $\begin{array}{l}\text { Loans with guarantees } \\
(\%)^{\wedge}\end{array}$ & 16.7 & 45.6 & 5.5 & 8.8 & 14.3 & 14.1 \\
\hline
\end{tabular}

Table 3: Characteristics of project finance versus other syndicated loan samples. * indicates that based on a two-sample t-test assuming unequal variances, the difference between the value for this facility and the value for project financing is significant at 5 percent significance. All other values are not statistically significant at 5 percent or higher. ${ }^{\wedge}$ indicates that the t-test has not been applied to these variables.

These findingssuggest that institutionsare compensated by relatively high up-front fees to motivate participation in project finance lending as well as being generallyless inclined to maintain large stakes in project finance facilities compared with other forms of credit.

These results also suggest that in terms of facility tenor, spread over LIBOR, structuring cost, the number of tranches and the number of syndication parties, the 
sukuk offerings are very similar to project financing deals observed, while other traditional loan facilities exhibit a significantly different facility size and tenor and number of average syndication parties. They key characteristics of spread and maturity however show that project finance facilities in the resources sector are largely aligned with the risk and loan maturity levels observed for Islamic fund investors.

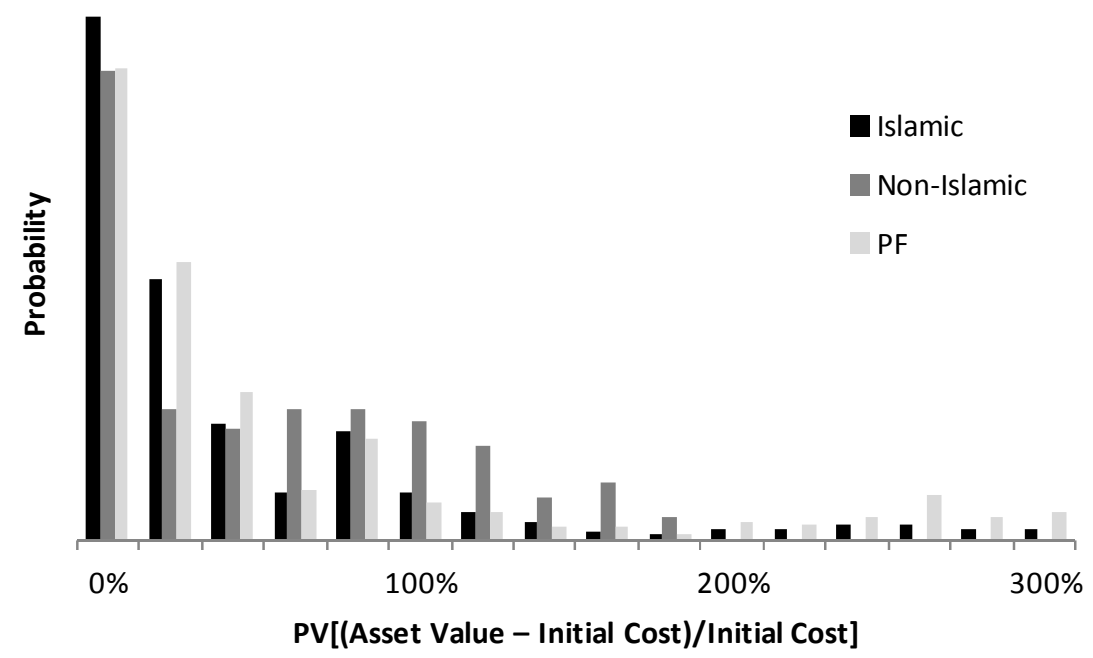

Figure 2: Distribution of asset returns from Islamic and non-Islamic project financing measured against project-financed investments in the resources sector, 2000-12.

Figure 2 outlines the distribution of asset returns from explicit Islamic and nonIslamic project financing deals measured against project-financed investments in the resources sector over 2000-12 using the same data sets as above. Asset returns are given as the present value of the current estimated asset value relative to the initial investment cost. The distribution of Islamic project finance investments closely replicates the distribution of project finance facilities in the resources sector, particularly at the upper and lower extremes which indicates a greater tolerance of Islamic investors to the risks and returns in natural resources project finance activities. Non-Islamic investments have a distribution of returns that is highly dense around the 50-150 percent level which suggests a broad level of risk aversion by nonIslamic project financiers who look to invest in projects that on average at least break even. Importantly however they also experience significantly fewer returns than Islamic project financiers below the 50 percent level. Discounting those projects that 
fail and earn zero return, Islamic investors experience a much broader spread of returns which is more naturally aligned with the distribution of returns in resource sector project financiers.

The similarity in investment risk and return profiles, funding costs and facility tenor suggest that Islamic investors are very well suited to project financing in the global resources sector. While Islamic funds currently invest heavily in this sector in the Middle East there appears to be significant alignment between Islamic investors and resource companies seeking funding through project finance structures.

\section{Examples of Islamic-sourced funds for the resources sector}

There are a number of precedents that highlight the success of the Islamic funds financing projects outside Islamic nations. The first high-profile example of a Western-based sukuk offering was the financing of oil and gas production activities in the Gulf of Mexico by the East Cameron Gas Company (ECGC) based in Texas in 2006, Richardson (2006). The project raised \$166 million through a sukuk offering to finance capital and operating costs associated with drilling and operating wells. To avoid issues associated with riba the funds raised were also used to eliminate outstanding conventional debt.Importantly thesukuk offer was non-recourse to ECGC, meaning that if the royalty could not generate sufficient funds, ECGC would not be obligated to pay the sukuk holders. ECGC thusassumed the risk associated with below-expected oil/gas production and falling off-take prices. The sukuk offering was Shari'ah-compliant due to the risk sharing on the part of the sukuk holders as well as the characterization under Louisiana law of a royalty interest as real property, of which the sukuk holders held undivided beneficial ownership. This undivided beneficial ownership could be considered a form of partial title in the royalty interest. Islamic scholars issued a fatwa approving of the deal, see Richardson(2006). Shari'ah compliance required theretention of title in the assets underlying the project therefore investors shared in the project risks and received rental paymentsfrom production in contrast to traditional interest payments. ECGC was a high-risk project that ultimately defaulted butthe structure of the facility demonstrates howsukuk offerings combined with the other necessary forms of Shari'ah-compliant funding are a lucrative source of funds for project financing in the resources sector.

Non-resources sector examples include the 2005 Jimah Energy Ventures (JEV), a company owned by the royal family of the Malaysian state of Negeri Sembilan who raised US\$1.6bn to fund the construction of a 1400 MW Greenfield independent power producer (IPP). Much of the capital was raised by sukuk however the deal also included a significant amount of conventional finance through a bank guarantee 
facility and a standby letter of credit. ${ }^{2}$ Long-dated project financing examples where tenors of 20 years or more have been achieved include the Rabigh IPP in Saudi Arabia and Shuweihat 2 projects in Abu Dhabi.

Not all project financing deals involve high risk assets. Some firms have used project finance for activities that have a low cost of financial distress. Many resource projects contain economically independent but tangible assets that do not lose much value during default or after restructuring. Because the assets have few alternative uses an efficient restructuring is generally more likely than an inefficient liquidation, see Esty(2002). The recognition that projects maintain a similar value to that of a going concern encourages both subordinate and senior claimants to prefer rapid restructurings to alternative uncertain outcomes. This phenomenon clearly benefits Islamic financiers.

One key drawback of Islamic financing is the lack of a forum for reaching consensus on issues relating to Shari'ah compliance through a regulatory body. The Islamic Financial Services Board publishes various technical standards for financial institutions while other institutions including the International Islamic Financial Market, the Liquidity Management Centre and the International Islamic Rating Agency lend some support to standardizing Islamic financing principles. However the regulatory frameworks do not explicitly create a universal set of rules. The lack of regulation could make Islamic finance more country-specific or even Shari'ah boardspecific, which would limit potential sources of capital. A more uniform approach to regulation by a sanctioned Shari'ah compliance body can address this deficiency and permit Islamic and even conventional financial institutions to offer compliant Shari'ah financing.

Another issue concerning the viability of Islamic financing in some countries is level and degree of regulation on Islamic banking and financing practices as well as any legislative measures that may be implemented to accommodate such practices as highlighted by Ahmad and Hassan(2009). However we expect that although Muslims and dedicated Islamic banks are in the minority in many resource-rich countries, regulatory authorities would act to ensure a level playing field among Islamic and conventional institutions, and may even result in a greater number of conventional institutions engaging in Shari'ah-compliant financing.

\section{Concluding Remarks}

Islamic finance is more suited to certain type of projects than others. Islamic finance lends itself more to projects that incorporate a discrete set of assets that can be owned

\footnotetext{
2 “Jimah Energy: Upfront Equity,” Project Finance, London: June 2005.
} 
by the Islamic financiers without too much potential intrusion on the enjoyment of such rights by conventional banks under inter-creditor arrangements, see for instance Jobst(2007). Furthermore the assets owned by the Islamic financiers must be separable and have an economic value as stand-alone assets. Islamic funding principles offer a natural fit with the desirable features of project finance opportunities, particularly in the global resources sector. This is a source of untapped potential.

The key to Shari'ah compliance is to facilitate the retention of title in the project's assets by Islamic lenders. Once the lender has title to these assets they are subject to the risks of the project and any return on the investment will be in the form of rents on the assets, as opposed toriba. Shari'ah-compliant financing is well-suited for

project finance due to the nature of the projects typically undertaken in project finance transactions. Such projects tend to be large industrial or infrastructure projects whose cash flows can be projected to some extent, which avoids the prohibition on gharar.So long as the project does not facilitate activity that is haram the project is generally Shari'ah-compliant.

For Islamic investors project finance opportunities in the resources sector offers an avenue not only for investment, but also for infrastructure development and economic diversification. As competition for access to Islamic funds increases those project finance investors with the greatest understanding and willingness to work with Shari'ah-compliant finance practices can gain an advantage in accessing an important alternative source of capital.

\section{References}

Abdel-Khaleq, Ayman H. andChristopher F. Richardson, "New Horizons for Islamic Securities: Emerging Trends in Sukuk Offerings,"Chicago Journal of International Law, Volume 7, Issue 2 (2007):409-425.

Abdul-Mumin, Abdulai and ChamhuriSiwar, "Linking Sustainable Livelihoods to Natural Resources and Governance in OIC Countries: Prospects and Challenges," Journal of Economic Cooperation and Development, Volume 32, Issue 2 (2011): 97-123.

Ahmad, A.U.F. andM. Kabir Hassan, "Legal and Regulatory Issues of Islamic Finance in Australia," International Journal of Islamic and Middle Eastern Finance and Management, Volume 2, Issue 4 (2009): 305-322.

Davis, Henry A. “The Definition of Structured Finance: Results from a Survey,"Journal of Structured Finance, (Fall, 2005): 5-10. 
Dusuki, Asyraf Wajdi "Commodity Murabahah Programme (CMP): An Innovative Approach to Liquidity Management," Journal of Islamic Economics, Banking and Finance, Volume 3, Issue 1 (2007): 1-23.

Esty, Benjamin C. "Returns on Project-Financed Investments: Evolution and Managerial Implications,"Journal of Applied Corporate Finance, Volume 15, Issue 1(2002): 71-86.

Esty, Benjamin C. andWilliam L. Megginson, "Creditor Rights, Enforcement and Debt Ownership Structure: Evidence from the Global Syndicated Loan Market,"Journal of Financial and Quantitative Analysis, Volume 38, Issue 1 (2003): 37-59.

Gilson, S.C., John, K. andLang, L.H.P. “Troubled Debt Restructurings: An Empirical Study of Private Reorganization of Firms in Default,"Journal of Financial Economics, Volume 27 (1990):315-353 .

Harris, M. andRaviv, A. "The Theory of Optimal Capital Structure,"Journal of Finance, Volume 48 (1991): 297-365.

Hasan, Zulkifli, "A Survey on Shari'ah Governance Practices in Malaysia, GCC Countries and the UK: Critical Appraisal," International Journal of Islamic and Middle Eastern Finance and Management, Volume 4, Issue 1 (2011): 30-51.

Holden, Kelly,"Note, Islamic Finance: Legal Hypocrisy Moot Point, Problematic Future Bigger Concern,"Boston University International Law Journal, Volume 25 (2007): 341-367.

Javaid, Shahid Hussain, "Dutch Disease Investigated: Empirical Evidence from Selected South-East Asian Economies," Journal of Economic Cooperation and Development, Volume 32, Issue 4 (2011): 51-74.

Jobst, Andreas A.,"The Economics of Islamic Finance and Securitization,"Journal of Structured Finance, (Spring, 2007): 6-27.

Kleimeier, S. andMegginson, W.L. "Are Project Finance Loans Different from Other Syndicated Credits?"Journal of Applied Corporate Finance, Volume 13, Issue 1 (2000): 75-87.

Lewis, Mervyn.K., "In What Ways Does Islamic Banking Differ from Conventional Finance," Journal of Islamic Economics, Banking and Finance, Volume 4, Issue 3 (2008): 9-24.

Mahlknecht, Michael,Islamic Capital Markets and Risk Management. London: Risk Books, 2009.

McMillen, Michael J.T., "Islamic Shari'ah-Compliant Project Finance: Collateral Security and Finance Structure Case Studies,"Fordham International Law Journal,Volume 24 (2001):1184-1186. 
Merton, Robert C., “A Simple Model of Capital Market Equilibrium with Incomplete Information,"Journal of Finance, Volume 42 (1987):483-510.

Mian, A. andSantos J., “Liquidity Risk and Maturity Management,” Working Paper, Berkeley, 2011.

Niehuss, John M., International Project Finance in a Nutshell,Thomson Reuters: St. Paul, USA, 2010.

Rehman, Scheherazade S.,"Globalization of Islamic finance law,"Wisconsin International Law Journal, Volume 25, Issue 4 (2008): 625.

Richardson, Christopher F.,"Islamic Finance Opportunities in the Oil and Gas Sector: An Introduction to an Emerging Field,"Texas International Law Journal,Volume 42, Issue 1 (2006): 119-153.

Rosly, Saiful Azhar,"Shariah Parameters Reconsidered," International Journal of Islamic and Middle Eastern Finance and Management, Volume 3, Issue 2 (2010): 132-146.

Simshauser, Paul andNelson, Tim,"The Second-Round Effects of Carbon Taxes on Power Project Finance,"Journal of Financial Economic Policy, Volume 4, Issue 2 (2012): 104-127.

Smolo, Edib and M. Kabir Hassan, "The Potentials of Musharakah Mutanaqisah for Islamic Housing Finance," International Journal of Islamic and Middle Eastern Finance and Management, Volume 4, Issue 3 (2011):237-258.

Tacy, K.J. "Islamic Finance: A Growing Institution in the United States,"NC Banking Institute, Volume 10 (2006): 355-378.

Usmani, Muhammad Taqi,An Introduction to Islamic Finance. Kluwer Law International: The Hague, 2002.

Vishwanath, S.R. andSabahuddin Azmi, “An Overview of Islamic Sukuk Bonds,”Journal of Structured Finance,(Winter, 2009):58-67. 